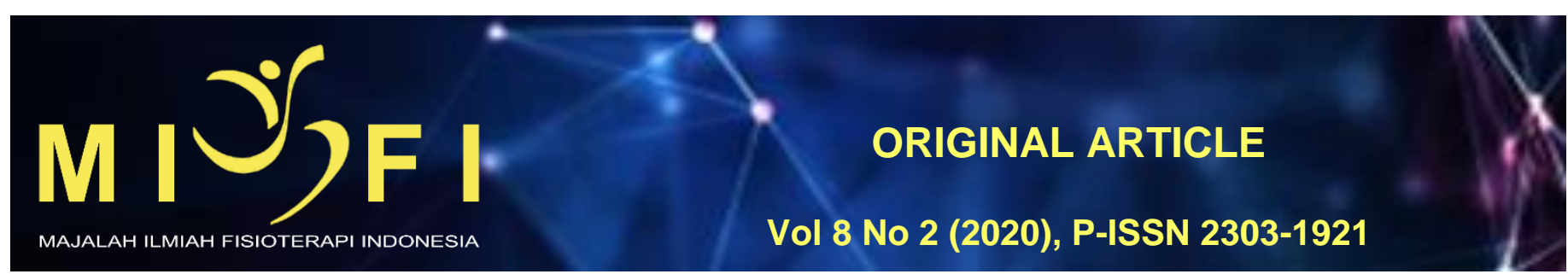

\title{
HUBUNGAN SIKAP KERJA DAN DURASI BERKENDARA TERHADAP KEJADIAN LOW BACK PAIN NON SPESIFIC PADA PENGEMUDI OJEK ONLINE DI KOTA DENPASAR
}

\author{
Muhammad Agung Satrio ${ }^{1}$, Indira Vidiari Juhanna ${ }^{2}$, I Made Niko Winaya ${ }^{3}$, Ari Wibawa ${ }^{4}$ \\ ${ }_{1}^{1}$ Program Studi Sarjana Fisioterapi dan Profesi Fisioterapi, Fakultas Kedokteran Universitas Udayana \\ ${ }^{2}$ Departemen Fisiologi Fakultas Kedokteran Universitas Udayana \\ 3,4Departemen Fisioterapi Fakultas Kedokteran Universitas Udayana \\ muhammad.agung96@gmail.com
}

\begin{abstract}
ABSTRAK
Low back pain non specific merupakan salah satu gangguan muskuloskeletal yang terjadi didaerah punggung bawah yang belum ada identifikasi jelas mengenai penyebab rasa sakit yang timbul. Namun secara umum disebakan oleh aktivitas tubuh yang kurang baik seperti sikap kerja membungkuk dan durasi berkendara berlebih. Tujuan penelitian ini adalah mengetahui hubungan sikap kerja dan durasi berkendara terhadap kejadian low back pain non spesific pada pengemudi ojek online di Kota Denpasar. Penelitian ini adalah penelitian analitik cross sectional yang dilakukan bulan April 2019. Sampel dalam penelitian ini adalah 66 orang pria rentang usia 30-40 tahun. Teknik pengambilan sampel dengan teknik consecutive sampling. Variabel independen dalam penelitian ini sikap kerja yang diukur menggunakan metode REBA dan durasi berkendara yang diketahui melalui kuesioner. Sedangkan variabel dependen dalam penelitian ini adalah low back pain non spesific diketahui dengan assessment fisioterapi. Teknik analisis data yang dilakukan yaitu uji bivariat dengan Spearman's Rho untuk mengetahui ada atau tidaknya hubungan, kekuatan hubungan dan arah hubungan. Berdasarkan hasil output uji analisis data diketahui bahwa nilai $p=0,001(p<0,05)$ pada sikap kerja dan nilai $p=0,000(p<0,05)$ untuk durasi berkendara yang berarti nilai signifikan. koefisien korelasi sebesar 0,390 untuk sikap kerja dan 0,538 untuk durasi berkendara yang berarti memliki kekuatan hubungan yang cukup, arah hubungan positif yang berarti searah. Berdasarkan hasil penelitian maka dapat disimpulkan bahwa terdapat hubungan yang signifikan, searah dengan kekuatan sedang antara sikap kerja dan durasi berkendara terhadap kejadian low back pain non specific pada pengemudi ojek online di Kota Denpasar.
\end{abstract}

Kata Kunci : sikap kerja, durasi berkendara, low back pain non spesific

\section{THE CORRELATION BETWEEN WORK ATTITUDE AND RIDING DURATION TOWARD LOW BACK PAIN NON SPESIFIC INCIDENT TO OJEK ONLINE MOTOR-RIDER IN DENPASAR}

\begin{abstract}
Non-specific low back pain is one of the musculoskeletal disorders that occurs in the lower back area where there is no clear identification of the specific cause of the pain. But in general, it can be caused by poor body activities such as stooped work posture and excessive riding duration. The purpose of this study was to determine the correlation of work attitude and duration of riding to the incidence of non-specific low back pain in ojek online motor-rider in Denpasar City. This study was a cross sectional analytic study design conducted in April 2019. The number of samples in this study were 66 men with an age range of 30-40 years. The sampling technique was done by consecutive sampling technique. The independent variable in this study is the work attitude that is measured using the REBA method and the riding duration known through interviews or questionnaires. While the dependent variable in this study is the non-specific low back pain that is known by the physiotherapy assessment form. The data analysis technique is done by bivariate test with Spearmans Rho to find out whether there is a relationship, the strength and the direction of the relationship. The resulted of the study based on data analysis test output showed that the value of $p=0.001(p<0.05)$ on work attitudes and the value of $p=0,000(p<0.05)$ for riding duration which means significant value. correlation coefficient is 0.390 for work attitude and for riding duration is 0.538 which means that there is sufficient relationship strength and the direction of a positive relationship which means in the same direction. Based on the results of these studies it can be concluded that there is a significant relationship, in the direction of moderate strength between work attitudes and duration of riding towards the incidence of non-specific low back pain in ojek online motor-rider in Denpasar City.
\end{abstract}

Keyword : work attitude, riding duration, non spesific low back pain 


\section{PENDAHULUAN}

Transportasi merupakan salah satu sarana perhubungan yang sangat penting dalam segala hal aktivitas manusia. Hal ini terlihat dari munculannya moda transportasi berbasis online pada kota besar di Indonesia ${ }^{1}$. Namun, ada beberapa hal yang tidak diperhatikan oleh pengemudi ojek online ketika bekerja dalam kesehariannya yaitu lama berkendara dan posisi duduk diatas motor yang tidak baik dan benar. Saat ini yang sering terjadi pada pengemudi ojek online yaitu masalah nyeri punggung bawah non spesifik atau low back pain non spesific. fenomena ini diakibatkan oleh duduk lama diatas motor dengan posisi yang salah sehingga menyebabkan kerusakan jaringan di area punggung bawah. Data WHO pada tahun 2017 Prevalensi dari Low Back Pain non spesific diperkirakan 60\% hingga $70 \%$ di negara-negara industri dan prevalensi satu tahunnya $15 \%$ hingga $45 \%$, insiden dewasa $5 \%$ per tahun. Negara maju seperti Amerika Serikat menunjukkan 15\%-20\% per tahun dan sebanyak 90\% kasus Low Back Pain disebabkan oleh kesalahan posisi tubuh dalam bekerja ${ }^{2}$.

Beberapa faktor risiko yang mempengaruhi nyeri punggung bawah diantaranya adalah, faktor individu meliputi, usia, jenis kelamin, indeks masa tubuh, aktivitas fisik, masa kerja. faktor pekerjaan meliputi posisi kerja, beban kerja, repetisi dan durasi. faktor lingkungan meliputi getaran dan kebisingan ${ }^{3}$. Salah satu faktor risiko yang berperan penting dan memiliki hubungan dengan pekerjaan adalah masalah sikap kerja duduk yang tidak baik dan benar serta durasi berkendara berlebih.

Sikap kerja merupakan penilaian kesesuaian antara alat kerja dan digunakan oleh pekerja dalam bekerja dengan ukuran antropometri pekerja yang ditentukan ${ }^{4}$. Menjalankan pekerjaan dengan sikap kerja duduk yang tidak baik dan benar dapat menimbulkan masalah muskuloskeletal terutama masalah punggung bawah ${ }^{5}$.

Durasi berkendara menjadi faktor selanjutnya yang mempengaruhi kejadian Low Back Pain non spesifik. Sistem dan manajemen durasi berkendara menjadi salah satu sumber potensial dari tekanan di tempat kerja ${ }^{6}$. Jika merujuk pada UU No. 22 Tahun 2009 tentang lalu lintas dan angkutan jalan, pada pasal 90 ayat (2) dijelaskan waktu kerja bagi pengemudi kendaraan bermotor umum sebagaimana dimaksud pada ayat (1) paling lama 8 jam sehari. Sedangkan pada pasal 90 ayat (3) disebutkan pengemudi kendaraan bermotor umum setelah mengemudikan kendaraan selama 4 jam berturut-turut wajib beristirahat paling singkat setengah jam ${ }^{7}$. Dengan kondisi posisi duduk statis dalam jangka waktu yang lama dapat memunculkan ketegangan di otot-otot daerah punggung dan pembebanan yang berlebih pada vertebralis utamanya pada lumbal dan hal tersebut dapat memicu terjadinya keluhan pada punggung ${ }^{8}$.

Sikap kerja yang mengharuskan untuk duduk statis pada waktu yang lama dan dilakukan berkali-kali dalam jangka waktu tertentu, memiliki risiko terganggunya kesehatan terutama nyeri punggung bawah ${ }^{9}$, Hal tersebut dapat memicu terjadinya penurunan produktivitas kerja. Berdasarkan latar belakang masalah diatas, penulis tertarik untuk melakukan penelitian tentang hubungan sikap kerja dan durasi berkendara terhadap kejadian low back pain non specific pada pengemudi ojek online di Kota Denpasar.

\section{METODE PENELITIAN}

Penelitian ini merupakan penelitian observasional yang menggunakan rancangan penelitian analitik dengan metode cross sectional yang bertujuan untuk mengetahui hubungan sikap kerja dan durasi berkendara terhadap kejadian low back pain non spesfic pada pengemudi ojek online di kota Denpasar. Penelitian ini dilakukan pada bulan april sampai mei 2019 di pangkalan-pangkalan ojek online seputaran kota Denpasar. Sampel dalam penelitian ini berjumlah 66 orang dengan teknik pengambilan sampel consecutive sampling yaitu salah satu jenis non-probalitiy sampling. Jumlah sampel yang ada dan memenuhi kriteria inklusi dan eksklusi dimasukkan dalam penelitian sampai jumlah yang diperlukan terpenuhi. Kriteria inklusi penelitian ini yaitu bersedia menjadi sampel penelitian dengan mengisi dan menandatangani informed consent, berusia 30-40 tahun, memiliki indeks massa tubuh normal, aktivitas fisik sedang, masa kerja 2 tahun atau lebih dan menggunakan kendaraan bermotor vario techno. Sedangkan yang termasuk dalam kriteria eksluksi yaitu responden yang memiliki riwayat penyakit punggung (tumor, kanker, riwayat patah atau operasi tulang belakang). Variabel independen dalam penelitian ini adalah sikap kerja dan durasi berkendara, variabel dependen yaitu low back pain non spesific dan variabel kontrol pada peneltian ini adalah usia, jenis kelamin, IMT, masa kerja, aktivitas fisik dan jenis kendaraan.

Prosedur penelitian yaitu peneliti melakukan proses perijinan kode etik terlebih dahulu. Selanjutnya peneliti membuat informed consent yang harus ditandatangani subjek, bahwa subjek bersedia menjadi sampel penelitian ini sampai selesai. Peneliti memberikan penjelasan kepada subjek yang diteliti mengenai manfaat, tujuan, bagaimana penelitian ini dilakukan, setelah itu peneliti memberikan form data diri, kuesioner, pengukuran IMT untuk menginklusi dan eksklusi sampel. Setelah memenuhi jumlah minimal sampel, peneliti melakukan proses anamnesa fisioterapi untuk mengetahui keluhan low back pain non specific. Setelah itu melakukan pengambilan gambar dan video untuk menganalisa REBA sikap kerja berkendara subjek. Data dari hasil keseluruhan pengukuran tersebut akan diolah secara statistik dengan SPSS versi 25. Analisis data yang digunakan berupa uji univariat untuk mengetahui gambaran masingmasing variabel dan uji bivariat dengan Spearman's Rho digunakan untuk mengetahui hubungan, kuat hubungan dan arah hubungan variabel independen terhadap variabel dependen. Tingkat signifikansi yang digunakan adalah $95 \%$ yang berarti $\alpha=0,05$. Nilai $p<\alpha$ menunjukkan bahwa terdapat hubungan antara sikap kerja dan durasi berkendara terhadap kejadian low back pain non specific pada pengemudi ojek online di kota Denpasar.

\section{HASIL}

Jumlah sampel yang telah memenuhi kriteria inklusi dan kriteria eksklusi sebanyak 66 orang. Karakteristik responden berdasarkan usia, masa kerja, durasi berkendara, sikap kerja, kejadian low back pain non specific, low back pain non specific berdasarkan sikap kerja dan distribusi low back pain non specific berdasarkan durasi berkendara. 
Tabel 1. Distribusi frekuensi karakteristik responden

\begin{tabular}{|c|c|c|}
\hline Variabel & Frekuensi (f) & Persentase (\%) \\
\hline \multicolumn{3}{|l|}{ Usia } \\
\hline $30-35$ & 44 & 66,7 \\
\hline $35-40$ & 22 & 33,3 \\
\hline \multicolumn{3}{|l|}{ Masa Kerja } \\
\hline 2 Tahun & 31 & 47,0 \\
\hline 3 Tahun & 22 & 33,3 \\
\hline 4 Tahun & 13 & 19,7 \\
\hline \multicolumn{3}{|l|}{ Durasi Berkendara } \\
\hline Durasi Singkat $(<=4$ jam $)$ & 18 & 27,3 \\
\hline Durasi Tinggi (>4 jam) & 48 & 72,7 \\
\hline \multicolumn{3}{|l|}{ Sikap Kerja } \\
\hline Risiko Sedang & 49 & 74,2 \\
\hline Risiko Tinggi & 17 & 25,8 \\
\hline \multicolumn{3}{|l|}{ Gejala LBP non Spesific } \\
\hline $\mathrm{Ya}$ & 53 & 80,3 \\
\hline Tidak & 13 & 18,7 \\
\hline Jumlah & 66 & 100 \\
\hline
\end{tabular}

Tabel 1. menunjukkan bahwa dari 66 responden pengemudi ojek online di Kota Denpasar, kelompok usia 30 35 tahun sebanyak 44 orang (66,7\%) dan kelompok usia 35 - 40 tahun yaitu sebanyak 22 orang (33,3\%). Berdasarkan masa kerja, didapatkan hasil frekuensi pengemudi ojek online pada kelompok.masa kerja 2 tahun sebanyak 31 orang $(47,0 \%)$, masa kerja 3 tahun sebanyak 22 orang (33,3\%), dan masa kerja 4 tahun sebanyak 13 orang (19,7\%). Berdasarkan tabel diatas juga.didapatkan hasil 18 orang $(27,3 \%)$ kelompok durasi singkat kurang dari sama dengan 4 jam, dan 48 orang $(72,7 \%)$ kelompok durasi tinggi lebih dari 4 jam. Untuk sikap kerja didapatkan bahwa dari 66 responden,terdapat 49 orang (74,2\%) mengalami risiko sedang (Skor 4-7), 17 orang (25,8\%) mengalami risiko tinggi (Skor 8-10). Berdasarkan kejadian LBP non specific bahwa dari 66 responden terdapat 53 orang (80,3\%) mengalami gejala low back pain non spesific dan 13 orang (19,7\%) tidak mengalami gejala low back pain non specific.

Tabel 2. Distribusi kejadian low back pain non specific berdasarkan sikap kerja

\begin{tabular}{ccccc}
\hline & \multicolumn{3}{c}{ Sikap Kerja } & \multirow{2}{*}{ Total } \\
\cline { 2 - 4 } & \multirow{2}{*}{ Tidak } & Risiko Sedang & Risiki Tinggi & \\
\cline { 2 - 4 } LBP non Spesific & $(100 \%)$ & 0 & 13 \\
& \multirow{2}{*}{$\mathrm{Ya}$} & 36 & $(0 \%)$ & $(100 \%)$ \\
\hline \multirow{2}{*}{ Total } & & $(67,9 \%)$ & $(32,1 \%)$ & 53 \\
& & 49 & 17 & $60 \%)$ \\
& $(74,2 \%)$ & $(25,8 \%)$ & $(100 \%)$ \\
\hline
\end{tabular}

Berdasarkan Tabel 2. diketahui jumlah pengemudi yang memiliki risiko sikap kerja sedang memiliki frekuensi sebanyak 49 orang $(74,2 \%)$ dengan rincian sebanyak 13 orang tidak mengeluhkan low back pain non specific dan 36 orang mengeluhkan low back pain non specific. Sedangkan pengemudi yang memiliki risiko sikap kerja sedang memiliki frekuensi sebanyak 17 orang (25,8\%) dengan rincian total seluruhnya 17 orang mengeluhkan low back pain non specific.

Tabel 3. Distribusi kejadian low back pain non specific berdasarkan durasi berkendara

\begin{tabular}{ccccc}
\hline & \multicolumn{2}{c}{ Durasi berkendara } & \multirow{2}{*}{ Total } \\
\cline { 2 - 4 } & \multirow{2}{*}{ Tidak } & Durasi singkat & Durasi tinggi & \\
\cline { 2 - 4 } LBP non Spesific & 12 & 1 & 13 \\
& \multirow{2}{*}{$\mathrm{Ya}$} & 6 & $(7,7 \%)$ & $(100 \%)$ \\
\hline \multirow{2}{*}{ Total } & $(11,3 \%)$ & $(88,7 \%)$ & 53 \\
& & 18 & 17 & $66 \%)$ \\
& $(27,3 \%)$ & $(72,2 \%)$ & $(100 \%)$ \\
\hline
\end{tabular}

Tabel 3. Menunjukkan jumlah pengemudi yang berkendara dengan durasi tinggi memiliki jumlah paling besar sejumlah 48 orang (72,7\%) dengan rincian sebanyak 1 orang tidak mengeluhkan low back pain non spesific dan 47 orang mengeluhkan low back pain non spesific. Pengemudi yang berkendara dengan durasi singkat berjumlah 18 orang $(27,3 \%)$ dengan rincian sebanyak 12 orang tidak mengeluhkan low back pain non spesifik dan 6 orang megeluhkan low back pain non spesific.

Tabel 4. Hubungan Sikap Kerja, Durasi Berkendara terhadap kejadian low back pain non spesific

\begin{tabular}{ccc} 
& p & r \\
\hline Sikap Kerja & 0,001 & 0,390 \\
\hline Durasi Berkendara & 0,000 & 0,538
\end{tabular}

Berdasarkan Tabel 4. Hasil output data menunjukkan bahwa diketahui nilai p sikap kerja sebesar 0,001 dan nilai $p$ durasi berkendara 0,000 yang berarti lebih kecil dari nilai signifikansi 0,05 sehingga dapat dinyatakan signifikan. 
Nilai $r$ (koefisien korelasi) dari sikap kerja sebesar 0,390 dan durasi berkendara 0,538 yang menunjukkan keeratan korelasi yang sedang sehingga dapat disimpulkan risiko sikap kerja dan durasi berkendara terhadap kejadian low back pain non spesific pada pengemudi ojek online di Kota Denpasar memiliki kekuatan hubungan yang sedang, signifikan dan searah.

\section{DISKUSI}

\section{Karakteristik Sampel}

Responden yang dipilih merupakan pengemudi ojek online laki-laki usia 30-40 tahun di kota Denpasar. Hasil penelitian menunjukkan bahwa dari 66 orang sampel dipisahkan ke dalam 2 kategori. Kategori usia 30-35 tahun merupakan kategori dengan jumlah 44 orang $(66,7 \%)$ Sedangkan kategori usia 35-40 tahun dengan jumlah 22 orang $(33,3 \%)$. Usia memiliki hubungan dengan low back pain berdasarkan hasil penelitian yang dilakukan oleh Umami (2014) yang menyatakan bahwa usia lebih dari 30 tahun paling banyak mengalami tingkat keluhan nyeri punggung bawah ${ }^{10}$.

Kemudian dari masa kerja didapatkan hasil frekuensi pengemudi ojek online pada kelompok masa kerja 2 tahun sebanyak 31 orang $(47,0 \%)$, masa kerja 3 tahun sebanyak 22 orang $(33,3 \%)$, dan masa kerja 4 tahun sebanyak 13 orang (19,7\%). Masa kerja juga memiliki hubungan sesuai dengan penelitian yang dilakukan Ayuningtyas (2012) tentang hubungan antara masa kerja dengan risiko terjadinya nyeri punggung bawah non spesifik pada karyawan PT. Krakatau Steel di Cilegon Banten menyatakan bahwa terdapat hubungan antara masa kerja dengan risiko terjadinya nyeri punggung bawah ${ }^{11}$.

\section{Hubungan Sikap Kerja dengan Kejadian Low Back Pain non Spesific}

Berdasarkan hasil output yang diperoleh dari uji spearman's rho mengenai hubungan sikap kerja dengan kejadian low back pain non spesifik dengan nilai $\mathrm{p}$ yaitu sebesar 0,001 dan correlation coefficient dari postur kerja sebesar 0,390 yang memiliki interpretasi bahwa hubungan signifikan, keeratan korelasi yang cukup dan arah hubungan yang positif.

Hal tersebut didukung dengan penelitian yang dilakukan oleh Aditya (2012) dari 40 responden diketahui bahwa 36 responden $(90 \%)$ dengan sikap duduk tidak ergonomi dan 37 responden (92,5\%) mengalami nyeri punggung bawah ${ }^{12}$. Penelitian ini didukung juga oleh penelitian yang dilakukan oleh Padmiswari pada tahun 2016 yang menyatakan bahwa terdapat hubungan signifikan antara sikap duduk dengan nyeri punggung bawah dengan nilai $p$ sebesar 0,030 . Penelitian tersebut menunjukkan.bahwa sikap duduk yang tidak ergonomis sebanyak 32 orang $(66,7 \%)$ sedangkan sikap duduk yang ergonomis sebanyak 16 orang $(33,3 \%) .{ }^{22}$

Biomekanik sikap kerja duduk pada pengemudi ojek online yaitu posisi pelvic berputar kearah posterior atau posterior pelvic tilting akibat flatt-nya kurva vertebra lumbal maka terjadi kontraksi dan perubahan tensitas pada beberapa otot diantaranya otot hamstring, erector spine dan iliopsoas ${ }^{13}$. Saat duduk berkendara ligamen ligamen tulang belakang seperti posterior longitudinal ligamen dan otot erector spine akan cenderung mengalami kontraksi secara eksentrik dan mengeluarkan gaya lebih besar untuk mempertahankan posisi sehingga tidak jatuh kedepan. Sama halnya dengan otot iliopsoas dan anterior longitudinal ligamen, ketika duduk otot lliopsoas dan ligamen penunjang harus menarik tubuh ke depan untuk mempertahankan posisi sehingga tidak jatuh kebelakang ${ }^{14}$. Ketika otot berkontraksi, ketegangan yang meningkat menutup suplai darah ke otot tersebut. Ini membutuhkan periode relaksasi agar suplai darah kembali normal. Apabila hal ini tidak diperbaiki, maka akan menyebabkan penyakit akibat kerja dan penurunan kualitas hidup ${ }^{15}$. Oleh karena itu, peneliti menyimpulkan bahwa sikap kerja yang tidak ergonomis dan dilakukan berulang-ulang dapat meningkatkan resiko terjadinya low back pain non spesific.

\section{Hubungan Durasi Berkendara dengan Kejadian Low Back Pain non Spesific}

Berdasarkan pada tabel 4. mengenai korelasi durasi berkendara terhadap kejadian low back pain non spesific diketahui menggunakan uji statistik Spearman's nilai $p=0,000$ dan nilai correlation coefficient (koefisien korelasi) dari durasi berkendara dengan low back pain non spesific sebesar 0,583 yang memiliki interpretasi bahwa hubungan sangat signifikan, keeratan korelasi yang sedang dan arah hubungan yang positif. Hubungan positif ini berarti semakin lama durasi berkendara maka semakin meningkat risiko mengalami low back pain non specific.

Penelitian ini didukung juga oleh penelitian yang dilakukan Samara (2005) Sebanyak $60 \%$ orang dewasa mengalami nyeri punggung bawah dikarenakan aktivitas pekerjaan yang menuntut pekerjanya untuk duduk dalam waktu yang relatif lama, dan juga orang yang bekerja dengan posisi duduk selama setengah hari waktu kerja atau lebih, lebih memiliki risiko relatif 1,6 untuk terjadinya nyeri punggung bawah ${ }^{16}$. Berdasarkan penelitian yang dilakukan oleh Harkian (2014) menunjukkan bahwa seseorang dengan durasi duduk lebih dari 4 jam memiliki risiko 1,661 kali lebih besar mengalami kejadian nyeri punggung bawah dibandingkan dengan durasi duduk kurang dari 4 jam ${ }^{17}$. Semakin lama seseorang duduk maka ketegangan otot-otot sekitar punggung dan keregangan ligamentum-ligamentum pada punggung bawah semakin bertambah ${ }^{18}$. Keadaan tersebut menyebabkan daerah punggung bawah lebih sering terjadi gangguan maupun kerusakan sehingga terjadi kelelahan dan iskemia jaringan di sekitar daerah tersebut ${ }^{17}$.

Ketika duduk maupun berkendara otot-otot yang bekerja diantaranya adalah otot erector spine, internal oblique dan transversus abdominus. Ketiga otot ini termasuk kedalam otot rangka bertipe II atau fast twitch. Otot tipe ini memiliki serat otot yang berkonteraksi relatif cepat dan menghasilkan energi secara anaerobic atau tanpa menggunakan oksigen. Otot jenis ini memiliki ketahanan yang tidak terlalu baik atau mudah lelah ${ }^{19}$. Kelelahan otot erector spine terlihat setelah 37 menit bekerja ${ }^{20}$. Sedangkan otot punggung lainnya secara umum mulai terlihat ketidaknymanan pada awal 20 sampai 30 menit setelah bekerja duduk ${ }^{21}$. Jika sikap kerja pengemudi ojek online berada pada kondisi statis yang lama khususnya daerah lumbal, maka posisi dan gerakan yang terjadi selama berkendara mengakibatkan kelemahan pada otot punggung bagian bawah ${ }^{18}$. Hal ini dikarenakan gerakan yang tetap dan repetitif, dimana otot seiring digunakan 
ketahanannya semakin berkurang. Semakin lama pengemudi ojek online berkendara setiap harinya maka semakin tinggi pula risiko untuk mengalami keluhan MSDs dalam hal ini low back pain non spesific.

\section{SIMPULAN DAN SARAN}

Berdasarkan hasil dari analisis data yang telah dilakukan, dapat disimpulkan bahwa ada hubungan sikap kerja dan durasi berkendara terhadap kejadian low back pain non specific pada pengemudi ojek online di Kota Denpasar.

Saran kepada peneliti selanjutnya yang ingin menjadikan penelitian ini sebagai dasar penelitian ataupun ingin mengambil judul penelitian yang sama diharapkan dapat melakukan penelitian lebih lanjut dengan menambahkan variabel lainnya, dan juga melakukan persiapan lebih dini sebelum melakukan penelitian seperti mempersiapkan instrumen penelitian berupa kamera yang lebih canggih untuk memudahkan pengambilan foto dan video saat melakukan dokumentasi analisis foto REBA.

\section{DAFTAR PUSTAKA}

1. Akmal, M. El. Fenomena Pengemudi Taksi Online (Ditinjau Dari Teori Job Characteristic Model). Pemikiran \& Penelitian Psikologi; 2017. 12(3), 173-181.

2. IHME. Institute Health Metrics Evaluation. Global Burden of Disease Study 2017.Seattle USA; 2017.

3. Chaitow, L. Back Pain : A Movement Problem 1st edition. London UK: Churchill Livingstone; 2010.

4. Nurmianto. E. Ergonomi Konsep Dasar dan Aplikasinya. Edisi Kedua. Surabaya: Guna Widya; 2004.

5. Salvendy, G. Handbook Of Human Factors And Ergonomic 4th edition. New Jersey USA: John Wiley \& Sons, Inc; 2012.

6. ILO. Jam Kerja, Cuti, dan Upah. Jakarta : International Labour Organization; 2017. 4.

7. Fithry, A. Tinjauan Yuridis Undang-Undang Nomor 22 Tahun 2009 Tentang Lalu Lintas Dan Angkutan Jalan Terhadap Tingkat Kesadaran dan Kepatuhan Masyarakat Sumenep, 1(1 April); 2014. 1-9.

8. Branch, C. Evidence Based Management of Low Back Pain. USA: Elsevier; 2012.

9. Saputra, R. H. Hubungan Lama Berkendara Dengan Timbulnya Keluhan Nyeri Punggung Bawah Pada Pengendara Sepeda Motor. Skripsi, Program Studi Diploma Iv Fisioterapi Fakultas IImu Kesehatan Universitas Muhammadiyah Surakarta; 2009.

10. Umami, Hartanti, P.S. Hubungan antara Karakteristik Responden dan Sikap Kerja Duduk dengan Keluhan Nyeri Punggung Bawah pada Pekerja Batik Tulis . Jurnal Pustaka Kesehatan; 2004. Vol. 2, No.1

11. Ayuningtyas, S. Hubungan Antara Masa Kerja Dengan Risiko Terjadinya Nyeri Punggung Bawah (NPB) Pada Karyawan PT. Krakatau Steel di Cilegon Banten [Skripsi]. Program Studi DIV Fisioterapi Fakultas IImu Kesehatan Universitas Muhammadiyah Surakarta; 2012.

12. Aditya, M. I. Pengaruh Sikap Kerja Duduk Terhadap Keluhan Nyeri Punggung Bawah pada Pekerja Bagian Pelintingan Rokok di PT Djitoe Indonesia Tobacco. Skripsi. Program Studi Kesehatan Masyarakat Fakultas IImu Kesehatan Universitas Muhammadiyah Surakarta; 2012.

13. Anshar, \& Sudaryanto. Biomekanik Osteokinematika dan Arthokinematika Kementrian Kesehatan RI; 2011.

14. Neumann, Donald A. Kinesiology of the Musculoskeletal System. United States : Elsevier; 2010.251 - 285.

15. Mcgill, S.M., Hughson And Parks, K. Lumbar Erector Spinae Oxygenation During Prolonged Contractions: Implications For Prolonged Work. Ergonomics; 2000. 43: 486-493.

16. Samara, D., Basuki, B., \& Jannis, J. Duduk Statis Sebagai Faktor Risiko Terjadinya Nyeri Punggung Bawah Pada Pekerja Perempuan. Bagian Anatomi Fakultas Kedokteran Trisakti; 2005. 24(2), 73-79.

17. Harkian, Y., Dewi,R.L., Fitrianingrum, L. Hubungan antara Lama Duduk dan Sikap Duduk dengan Kejadian Nyeri Punggung Bawah di Poliklinik Saraf RSUD Dokter Soedarso Pontianak. Fakultas Kedokteran Pontianak; 2014.

18. Wijayanti, F. Hubungan Posisi Duduk Dan Lama Duduk Terhadap Kejadian Low Back Pain (Lbp) Pada Penjahit Konveksi Di Kelurahan Way Halim Bandar Lampung. Skripsi. Fakultas Kedokteran Universitas Lampung; 2017.

19. Martini, F. H., \& Nath, J. L. Fundamentals of Anatomy \& Physiology Ninth edition (9th edition). San Francisco: Pearson Education; 2012.

20. Halim, I., Omar, A. R., \& Othman, I. Assessment of Muscle Fatigue Associated with Prolonged Standing in the Workplace. Safety and Health Work; 2012. 3(1), 31-42. https://doi.org/10.5491/SHAW.2012.3.1.31

21. Waongenngarm, P., Rajaratnam, B. S., \& Janwantanakul, P. Internal Oblique and Transversus Abdominis Muscle Fatigue Induced by Slumped Sitting Posture after 1 Hour of Sitting in Of fi ce Workers. Safety and Health Work; 2016. 7, 49-54.

22. Padmiswari, N.K. Hubungan Sikap Duduk dan Lama Duduk terhadap Keluhan Nyeri Punggung Bawah pada Pengrajin Perak di Desa Celuk, Kecamatan Sukawati. E journal medika; 2016. 6 (2) : 1-10 Fakultas Kedokteran Universitas Udayana. 